\title{
On war, survival, and serendipity
}

\author{
Tam-Tri Le \\ Centre for Interdisciplinary Social Research \\ Phenikaa University, Hanoi, Vietnam
}

2022 January 16

OSF Preprints

When thinking about a "golden age" of impactful innovations across recent global history, we often refer to the glorified Industrial Revolution in the $18^{\text {th }}$ and $19^{\text {th }}$ centuries, started by breakthroughs in manufacturing processes and systems in Great Britain (Chiến \& Hoàng, 2015). But were these powerful initiatives mainly driven by humanity's noble pursuits of intellect and virtue?

Professor Priya Satia, an expert of modern British history from Standford University, argued that the Industrial Revolution in Britain began with the need for war supplies (Satia, 2019). "We need to stop thinking that Britain invented industrialism because it had an especially laissez-faire government or because it had a unique entrepreneurial genius or culture," Professor Priya Satia said. "Let's acknowledge the fact that Britain was involved in a lot of wars, and in order to pursue those wars, the government needed arms. And the British government clearly encouraged innovation within their gun industry." (Satia, 2018).

Human history is filled with conflicts, big and small, direct and subtle. Breakthroughs fueled by desires to overpower one's enemies were not limited to military innovations but also the development of social systems; from early politics and institutions to modern weapons and advanced warfare and governance, innovation holds the central position in humans' long and rather gruesome history of war (Lee, 2016). While intraspecific conflicts exist in many animals, humans are special for our ability to formulate complex strategies and find ways to manipulate opposing groups (Von Clausewitz, 2008). As the famous ancient book "The Art of War" suggests, a good strategy and its execution require not only military prowess as background conditions but also the ability to notice and assess information from direct observation on the battlefields (Tzu, 2021). Humans always aim to survive and thrive to ensure even better survival chances in the future. The desire to become the "fittest" in both natural and social environments motivates people to seek information that helps achieve such goals. This is the base for innovations - the power for gaining an edge in the never-ending survival battle.

In wars, humans have been trying to develop the best tactics and devices. It is the information processes of innovation, which incorporates serendipity (Napier \& Vuong, 2013), the Mindsponge mechanism of information processing (Nguyen et al., 2021; Vuong \& Napier, 2015), and the 3D framework of creativity (Vuong \& Napier, 2014) into an integral operation (Q.-H. Vuong et al., 2022). 
Update: More detailed discussions in the full book "A New Theory of Serendipity: Nature, Emergence and Mechanism" (see References).

\section{Acknowledgement}

I would like to thank my mentor Dr. Quan-Hoang Vuong and my friend Minh-Hoang Nguyen for the insights.

\section{References}

Chiến, B. N., \& Hoàng, V. Q. (2015). Bằng chứng cuộc sống: Suy ngẫm về phát triển bền vững Việt Nam. Hà Nội: Nhà xuất bản Chính trị Quốc gia Sự Thật.

Lee, W. E. (2016). Waging War: Conflict, Culture, and Innovation in World History. Oxford: Oxford University Press.

Napier, N., \& Vuong, Q. H. (2013). Serendipity as a Strategic Advantage? In T. Wilkinson (Ed.), Strategic Management in the 21st Century (pp. 175-199). Westport, CT: Praeger/ABC-Clio.

Nguyen, M.-H., et al. (2021). Alice in Suicideland: Exploring the Suicidal Ideation Mechanism through the Sense of Connectedness and Help-Seeking Behaviors. International Journal of Environmental Research and Public Health, 18(7), 3681. doi:10.3390/ijerph18073681

Satia, P. (2018, 2018/05/03/). War drove 18th-century Industrial Revolution in Great Britain. Retrieved from https://news.stanford.edu/2018/05/03/war-drove-18th-century-industrial-revolutiongreat-britain/

Satia, P. (2019). Empire of guns: the violent making of the Industrial Revolution. Stanford: Stanford University Press.

Tzu, S. (2021). The art of war. New York: Vintage.

Von Clausewitz, C. (2008). On war. Princeton, New Jersey: Princeton University Press.

Vuong, Q. H., \& Napier, N. K. (2014). Making creativity: the value of multiple filters in the innovation process. International Journal of Transitions and Innovation Systems, 3(4), 294-327. doi:10.1504/IJTIS.2014.068306

Vuong, Q. H., \& Napier, N. K. (2015). Acculturation and global mindsponge: An emerging market perspective. International Journal of Intercultural Relations, 49, 354-367. doi:10.1016/j.ijintrel.2015.06.003

Vuong, Q.-H., et al. (2022). Covid-19 vaccines production and societal immunization under the serendipity-mindsponge-3D knowledge management theory and conceptual framework. Humanities and Social Sciences Communications, 9, forthcoming.

Quan-Hoang Vuong. (2022). A New Theory of Serendipity: Nature, Emergence and Mechanism. Berlin, Germany: De Gruyter. 